Chirurgia (2020) 115: 314-322

No. 3, May - June

Copyright@ Celsius

http://dx.doi.org/10.21614/chirurgia.115.3.314

\title{
How to Write a Clinical Paper: Basics, Tips, Traps - Part I
}

\author{
Florin Botea ${ }^{1,2}$, Irinel Popescu ${ }^{1,2^{*}}$ \\ ${ }^{1}$ Center of General Surgery and Liver Transplantation, Fundeni Clinical Institute, Bucharest, Romania \\ ${ }^{2}$ Faculty of Medicine, University "Titu Maiorescu", Bucharest, Romania
}

*Corresponding author: Professor Irinel Popescu Center of General Surgery and Liver Transplantation, Fundeni Clinical Institute, soseaua Fundeni 258 Bucharest, Romania, 022328 E-mail: irinel.popescu220@gmail.com

\section{Rezumat \\ Cum se redactează o lucrare științifică: principii, sfaturi, capcane \\ - Partea I}

Unul dintre obiectivele principale ale clinicienilor este îmbunătățirea constantă a asistenței medicale, prin transferul de expertiză şi prin implementarea de inovații. Prin urmare, activitatea publicistică este extrem de importantă. Mai mult, această activitate este poate la fel de importantă şi pentru dezvoltarea carierei academice. Toată lumea medicală, de la studenți la medici seniori, avansează publicând lucrări şi obținând citarea acestora. Învățarea modului optim de a redacta o lucrare ştiințifică şi de a o trimite către revistele de specialitate ar trebui să fie un obiectiv pentru toți studenții, rezidenții, clinicienii şi cercetătorii. Scopul lucrării de față, publicată în 3 părți, este de a asista pe cei interesați în scrierea şi publicarea în mod eficient a lucrărilor lor ştiințifice.

Cuvinte cheie: lucrare ştiințifică, articol clinic, abilități redacționale

\section{Abstract}

One of the main goals of clinicians is to constantly improve the healthcare by spreading their expertise and by introducing innovations in medical science. Therefore, publishing is of utmost importance. Moreover, publishing helps authors in developing their academic carrier. Everyone, from students to senior physicians and surgeons, advance in their carrier by 
publishing papers and by getting their work cited by others. Learning how to properly write and submit a manuscript should be a goal for all medical students, residents, clinicians and researchers. The aim of the current paper, published in 3 parts, is to enable the readers to write and publish their work effectively.

Key words: clinical paper, scientific article, writing skills

\section{Introduction}

One of the fundamental objectives of physicians and surgeons is to continuously improve the healthcare by spreading their expertise and developing and applying advancements in medical science. This can be achieved by contributing to the fund of medical knowledge through published innovative research, so the entire scientific community may know about it. Therefore, publishing clinical and research work is a critical part of the academic process. Nowadays, the publishing activity is commonly evaluated by the h-index, also called the Hirsch index or Hirsch number. This index was suggested in 2005 by Jorge E. Hirsch as a tool for determining the relative quality of physicists (1). The h-index is an author-level metric that is designed to measure both the productivity and citation impact of the publications of a researcher or clinician. It is based on the set of the researcher's most cited published papers and the number of citations that they have received in other publications. The $\mathrm{h}$-index correlates with obvious success indicators, from being accepted for research fellowships, holding positions at top universities, to winning the Nobel Prize (2).

Learning how to write an effective manuscript should be a goal for all medical students, residents, clinicians and researchers. Everyone, from students to senior physicians and surgeons, advance in their carrier by publishing papers and by getting their work cited by others. Finally, publishing makes one a better physician and surgeon over time.

\section{Before You Start Writing a Paper}

\section{Step I: looking back on your research}

A. Originality

- Did you do something interesting to share?

- Are you updated on the latest findings related to your topic?

- Is there value gained to publish a confirmatory paper?

- If disagreement exists in the literature, have you enough data to sustain one of the variants?

B. Correctness

- Did you verify your results by appropriate analysis?

- Did you check if they are significant?

- Are your methods valid and consistent?

- Do you know the limitations of your methods?

C. Relevance

- Do your findings tell a consistent story?

- Does your work address a hot topic?

- Did you find answers to a significant issue?

If all answers are "yes", then you can start writing your manuscript.

Tips

- Self-evaluate your work.

- -Ask your supervisor and colleagues for advice on manuscript.

\section{Step II: evaluate your goals}

What type of manuscript?

a. Full-Length Methodology Research

(Original articles)

Research articles are generally considered 
the most difficult to complete, since thorough experimentation, data collection and analysis are required prior to writing. Both basic science and clinical papers fall into this category. These articles will generally be divided into introduction, material and methods, results, and discussion/conclusion sections.

\section{b. Review Papers}

Review articles are a good approach for researchers to scrutinize the literature and create a solid source of knowledge in an area of interest. The data obtained in this way can often be used as a basis when writing related grants, lectures, theses and research articles. Reviews will also help others unacquainted with the subject get a quick overview of existing knowledge on a given topic $(3,4)$. Research articles and clinical reviews remain the mainstay of surgical journals. These articles are generally considered the most significant contributions any individual makes in their academic career.

\section{c. Systematic reviews}

Systematic reviews are a sub-type of review paper that uses systematic methods to collect significant published data and research studies, and integrate their findings qualitatively or quantitatively (5). Systematic reviews may investigate clinical tests, adverse effects, economic assessments (6), and public health, environmental and social interventions (7).

\section{d. Techniques paper}

Techniques papers are used to describe a procedure or novel operative approach or, occasionally, an entirely new type of operation, and demonstrate its efficacy in addressing unsolved or partially solved issue. A clear description of how to perform the technique is invaluable in this type of article. Images, photographs and/or illustrations, are often better than text when explaining a procedure. As told by others, "Great paper, poor art reject. Poor paper, great art - accept!" The weight in these articles is in favor of technical approach, with a short report of complications and long-term outcomes. Presentation format and suitability for specific journals should be considered carefully, as not all journals accept this type of article (8).

\section{e. Meta-analysis}

Meta-analysis can be performed when multiple scientific studies on the same topic are available, with each of the studies report findings that are expected to have a certain degree of error. The aim of this type of study is to derive a pooled estimate closest to the common fact analyzed by all studies (based on the identified error). The methodology involves specific statistics. Meta-analyses are often, but not always, important components of a systematic review procedure.

\section{f. Case Studies/Case report}

Case reports are written for interesting and rare disease presentations, noteworthy images with outstanding teaching value, and/or some novel aspect of disease management. They can include single-patient reports, a small series (two or more similar cases) and/or a more extensive review of cases previously reported in the literature (9). Case reports can be difficult to publish, as many case reports may have already been published on what one might think is novel, and often reviewers consider the report uninteresting. However, a case report that introduces a new idea that will contribute to better management of patients is likely to be accepted. Case reports and similar manuscripts, although potentially of interest, should generally not constitute most of the academic productivity. Authors should try and focus on the other article types that are more highly regarded.

\section{g. Letters/Rapid Communications/Short Communications}

Letters to the editor are written in response to a published article. They usually question the interpretation of a study or offer an alternative point of view according to personal experience. Furthermore, they can be used to disseminate data and ideas that otherwise might not be published (10). This type of article also offers the opportunity to cite relevant literature that the 
initial article had not referenced. It also can be an excellent adjunct to one's record of scholarly publication but, like case reports, should be used judiciously. However, many reviewers will not consider letters to the editor as equivalent to independent research articles.

\section{h. Other article types}

Other article types, including opinion or editorial-type articles, image reports, and quiz articles may be easier to publish and will allow the case to be presented. These are journalspecific and the reader is encouraged to review different journals and potentially consider these article types to report their case.

\section{Who is your audience?}

- Do you address to specialists in a field, multidisciplinary investigators or a general audience?

o Tips: You need to adapt the data and the writing style accordingly.

- Even for similar topics, journals have readers with different backgrounds.

- Each journal has its own style; read its articles to get an idea of what is accepted

- Is the readership worldwide or local?

\section{What journal?}

\section{Consider:}

- Aims and scope - the scope of a journal refers to what types of articles and topics the journal aims to publish. Often, the scope is linked to the aims, mission or purpose of the journal. Check the journal websites for the necessary details.

- Scholarly metrics of the journal:

- Journal citation metrics are the most popular method of assessing the importance of a journal via a measure of the average number of times other articles have referenced articles published in that journal. Journals with higher citation metrics are considered more prominent and, therefore, reach a larger audience;

- New metrics on how many times the articles were downloaded, shared on social and professional media (Twitter, LinkedIn, etc.), mentioned on news, etc. (PlumX/Mendeley, ResearchGate, Almetric, stats).

- It is recommended to consider a journal that is indexed by Journal Citation Reports and recognized by the United States National Library of Medicine and National Institutes of Health shared website, PubMed commons (http://www. ncbi.nlm.nih.gov/pubmed). While it is more difficult to publish a manuscript in such a peer-reviewed or refereed journal (listed on PubMed and the Journal Citation Reports), the end result of the peer-review process in these journals will be a better paper that will be read by more researchers. It is important to differentiate PubMed (high standards, access to articles is often not free) from PubMed Central (PMC) (lower quality standard, access to articles is free).

- Other factors suggestive of quality is when a journal is supported by a scientific, medical or surgical society, or belongs to well-known publishers, such as Elsevier, Wiley, Springer, and Taylor and Francis.

- Readership - the readership is largely determined by the scope and should be considered when choosing a journal in order to ensure that one reaches the intended audience (8).

- Open access - the size of the audience is important, and that may be significantly increased by publishing in an Open access Journal, where readers have free access to your article. However, you must pay attention at the charging fee for publishing in such journals.

- Current hot topics - go through recently published abstracts.

- Types of articles - e.g. most journals do not accept case reports.

- Asking colleagues for advice.

Ways to find Journals:

- by searching the lists of Journals that can be downloaded from the Internet;

- by searching on PubMed database 
articles using the keywords of interests, finding also the Journals that the articles were published in;

- by searching the National Library of Medicine (NLM) catalog using the same keywords, finding the titles of Journals containing the keywords.

Tips

- Sometimes it is necessary to lower your expectations and choose a lesser ranked journal than initially considered, or even go back to the laboratory or clinic to gather or to validate further data.

- Naturally, it is desirable to publish in a journal with a higher impact factor. However, at first it is recommended to choose a journal with a relatively low impact factor, with no charging fees.

- Only submit your manuscript once at a time.

- International ethics forbid multiple simultaneous submissions.

Traps

- Choosing unsuitable journals is one of the most common mistakes authors make, according to the American Journal Experts (AJE);

- Do Not gamble by submitting your manuscript to multiple journals;

- Avoid predatory journals (charge large fees to publish, not indexed in PubMed, poor peer review).

\section{Strategies to get citations}

The strategies to get citations are based on ways to increase the number of readers who in return would appreciate your work and cite it in their future published papers:

- Choose a high-impact journal;

- Create an appealing title;

- Choose carefully the keywords;

- Select an Open access journal;

- Write a high-quality paper.

\section{Writing a Quality Paper}

\section{Language}

Editors and reviewers may review your manuscript and decide based on basic criteria, like grammar or spelling. Therefore, besides the science, also the language needs to be sound. Correct grammar is essential to ensure the quality of your manuscript. About $20 \%$ of errors in the manuscripts are related to grammar, especially in case of determiners, prepositions, articles, subject-verb agreement, and verb forms.

Use past tense when presenting the results of previous works and the methods used in your study and the corresponding observations and results. Use the present tense when describing general facts (thus differentiating them from your findings), when the subject of the sentence is your study, when interpreting or hypothesizing on your findings, and when you formulate the conclusion of your paper.

Tips

- Consult the Guide for authors.

- Editors dislike poorly prepared papers.

\section{Sentences}

Each sentence should convey just one idea. To be a good writer you have to read well-written papers. The keys to successful writing are simplicity and clarity. Use the active tense is recommended.

The key is to be succinct and precise, without overlooking essential facts.

Traps

a. Redundancy:

- Don't copy and paste from a section to another.

- Avoid words with the same meaning. Examples: "In addition, a regression analysis of these data was also considered..." - POOR (use of "in addition" and "also" with the same meaning) $\rightarrow$ "A regression analysis of these data was also considered..." - GOOD. "After analyzing the findings, the experiment 
was then adjusted..." - POOR (use of "after" and "then" with the same meaning) $\rightarrow$ "After analyzing the findings, the experiment was adjusted..." GOOD.

- Avoid repeat the same descriptive word the same sentence. Example: "In this paper, a complex surgical technique for complex Klatskin tumor has been proposed." - POOR (use of the word "complex" twice) $\rightarrow$ "In this paper, a complex surgical technique for advanced Klatskin tumor has been proposed." - GOOD.

- Avoid circular sentences. Example: "In order to compare the differences between the two groups, we analyze the variables showed below, in order to determine if changes had occurred." POOR (describes twice, in slightly different terms) $\rightarrow$ "In order to compare the differences between the two groups, we analyze the variables showed below" - GOOD.

b. Avoid the lack of clarity (ambiguity):

- - Make sure to use correctly commas and hyphens. Examples: "Calcium regulated transcription" has a different meaning from "Calcium-regulated transcription". "For gene expression profiling, microarray analysis was performed, using microRNAs" - POOR (the second comma is misused) $\rightarrow$ "For gene expression profiling, microarray analysis was performed using microRNAs" - GOOD.

- Semi-colons should not be used instead of a comma or colon. Example: „The patients were grouped into four groups based on the technique used for liver transplantation, namely; right hemiliver living donor, right hemiliver split graft, left hemiliver living donor and left hemiliver split graft.” - POOR $\rightarrow$ „The patients were grouped into four groups based on the technique used for liver transplantation. The techniques were transplantation of right hemiliver living donor, right hemiliver split graft, left hemiliver living donor and left hemiliver split graft." - GOOD.

- Make sure that "which" is used correctly. Example: "Data were compared to the published data of McConnor et al, which showed..." - POOR ( "which" is misused, referring to McConor and not to the comparison) $\rightarrow$ "'Data were compared to the published data of McConnor et al, revealing that..." - GOOD.

- Avoid using vague expressions such as "higher rate" or "at a lower temperature".

- Avoid exaggeration - avoid exaggerated interpretations of your results but do indicate significance. Example: "A huge increase in the number of patients recorded in 2010 when compared to 2009 was recorded" - POOR ("huge increase" is an exaggeration) $\rightarrow$ "A significant increase in the number of patients recorded in 2010 when compared to 2009 was recorded ( $\mathrm{p}=0.02)$ - GOOD.

- Avoid expressions such as "novel", "revolutionary", "first ever", "groundbreaking".

- Avoid inconsistent tense - do not combine tenses in the same sentence. Example: "Before vessels in hilum were dissected, the hemilivers are mobilized" - POOR (use of different tenses - "were" and "are") $\rightarrow$ "Before vessels in hilum were dissected, the hemilivers were mobilized"' (GOOD). "In ten patients, a liver biopsy from the affected sites was performed" POOR (incorrect use of "was") $\rightarrow$ "In ten patients, liver biopsies from the affected sites were performed" - GOOD.

- Avoid unbalanced sentences - the parts "compared with" is referring to have to match-up: example: "The levels of CEA in non-smokers were compared with smokers..." - POOR (the comparison is not between the levels of CEA and the smokers) $\rightarrow$ "The levels of CEA in nonsmokers were compared with those in smokers..." - GOOD.

c. Avoid wordiness (using more words than needed) - almost $30 \%$ of style errors in the manuscript are due to wordiness. Wordiness distorts your sentences and conceals your ideas from readers: 
- One common source of wordiness is unnecessary intensifiers. Adverbial intensifiers such as "clearly," "essential," "quite," "basically," "rather," "fairly," "really," and "virtually" not only add verbosity to your sentences, but also lower your results' credibility.

- Another source of wordiness is nominalizations, i.e., nouns derived from verbs and adjectives paired with weak verbs including "be," "have," "do," "make," "cause," "provide," and "get" and constructions such as "there is/are." (19).

- Numbers at the start of the sentence. Example: "223 liver metastases (145 patients) that undergone liver resection, were investigated. Of these, 124 patients (198 liver metastases) were available for analysis in order to establish the longterm survival after hepatectomy for liver metastases." POOR (passive tense, number starting the sentence, too many words, repetition, using different terms for the same thing) $\rightarrow$ "We investigated 145 patients (with 223 liver metastases) who had undergone liver resection. There were 124 patients (with 198 liver metastases) available for survivorship analysis." - GOOD .

d. Avoid pretentious writing (claiming great merit or importance).

e. Avoid the use of jargon (words or expressions developed for use within a particular group of people).

f. Avoid the use of passive voice, whenever possible (more than $65 \%$ of style errors of the manuscript are due to the use of passive voice).

g. Avoid nominalizations (using nouns formed from verbs), by converting the nominalization into the main verb. Example: "Prof. McConnor will conduct research on the impact on ......" - POOR (nominalization) $\rightarrow$ "Prof. McConnor will research the impact on...." - GOOD

h. Avoid the misuse of "respectively" - two corresponding listings are necessary. Example: "The overall survival at various periods of time were $81 \%, 61 \%$ and $33 \%$, respectively" - POOR (the corresponding intervals are not mentioned) $\rightarrow$ The overall survival at 1, 3 and 5 years were $81 \%, 61 \%$ and $33 \%$, respectively" GOOD.

i. Avoid the misuse of "etc." / and "so on" their use should be restrained, and a full series of elements should be included in the text, especially when referencing the literature or defining fixed parameters, as tests, periods of time, etc. Examples: "The two groups of data were compared using a number of statistical methods including t-test, chi squared analysis, etc." - POOR (all tests must be mentioned) $\rightarrow$ "The two groups of data were compared using statistical methods that included t-test, chi squared analysis, ANOVA test, and regression analysis." "In contrast with published data, such as those of Hill et al. (20011), Barn et al (2015), Pop et al (2012), and so on, the parameters analyzed here show a different trend." - POOR (all authors should be mentioned) $\rightarrow$ "In contrast with published data, such as those of Hill et al. (20011), Barn et al (2015), Pop et al (2012), McGrall et al (2013), and Rokitanski (2017), the parameters analyzed here show a different trend."

\section{Paragraphs}

The paragraph usually starts by a topic sentence that opens the paragraph, followed by the information, data, ideas and finally a concluding sentence that closes the paragraph (if appropriate). Split the sentences whenever possible.

\section{Layout}

Apply the guidelines in the "Guide for authors" in terms of:

- Layout.

- Word limits for each section.

- Nomenclature.

- Abbreviations.

- Spellings (British vs. American). 
- Reference format.

- Number and type of illustrations and tables.

- Statistics.

Tips

- Keep font style and size, and line spacing throughout the text - double-spaced left aligned 12-point size font (Times New Roman, Arial or Verdana) is recommended.

- Use the same heading styles throughout and maximum three levels of headings.

- Use maximum 3 font sizes;

- Use maximum 3 typefaces;

- Number the pages.

- Number the lines when required by the Guide for authors.

- Order and title sections as required by the Guide for authors.

- Figures and Tables are usually placed together, after the References.

\section{Traps}

- Avoid emphasis (bold, italic, underlined text, etc);

- Avoid capitalization.

\section{Length}

Refer to the Guide for authors for word and graphic limits. Here are some general guidelines:

- Title: Short and informative;

- Abstract: 1 paragraph (<250 words);

- Introduction: 1.5-2 pages;

- Methods: 2-3 pages;

- Results: 6-8 pages;

- Discussion: 4-6 pages;

- Conclusion: 1 paragraph;

- Figures: 6-8 (one per page);

- Tables: 1-3 (one per page);

- References: 20-50 papers (2-4 pages).

Letters or short communications have narrower limits, usually 3000 words and maximum five figures or tables.

\section{Abbreviation}

- Identify non-standard abbreviations on first use in the abstract and the main text.
- Refer to the Guide for authors for the standard abbreviations that don't need defining.

- Don't abbreviate terms used only few times in the entire manuscript.

- Acronyms: capitals required only in case of a proper noun or start of a sentence example: "colorectal liver metastasis (CLM)" NOT "Colorectal Liver Metastasis (CLM)".

\section{Standard systems}

It's important to use standard systems for numbers and nomenclature, e.g:

- For chemicals, use the conventions of the International Union of Pure and Applied Chemistry and the official recommendations of the IUPAC-IUB Combined Commission on Biochemical Nomenclature;

- For species, use the international taxonomical nomenclature (WoRMS: World Register of Marine Species, ERMS: European Register of Marine Species), and format them in italics.

- For units of measurement, use the International System of Units (SI).

\section{Language Editing Services}

Your work is valuable, so it is worth to invest in it. Services for scientific and medical editing are available, with costs that start from $\$ 8$ per page. However, the use such service is not obligatory and will not guarantee acceptance for publication. Recommended services include:

- American Journal Editing.

- Asia Science Editing.

- Diacritech Language Editing Service.

- Edanz Editing.

- Editage.

- International Science Experts.

- Liwen Bianji.

- SPI Publisher Services.

\section{Conflict of Interest}

The authors declare no conflicts of interests. 


\section{References}

1. Hirsch J E. An index to quantify an individual's scientific research output. PNAS. 2005;102 (46): 16569-72. arXiv:physics/0508025.

2. Bornmann L, Daniel HD. What do we know about the h-index? Journal of the American Society for Information Science and Technology. 2007;58 (9): 1381-1385.

3. McKillop IH, Moran DM, Jin X, Koniaris LG. Molecular pathogenesis of hepatocellular carcinoma. The Journal of surgical research. 2006;136(1):125-35.

4. Koniaris LG, McKillop IH, Schwartz SI, Zimmers TA. Liver regeneration. Journal of the American College of Surgeons. 2003; 197(4):634-59.

5. Armstrong R, Hall BJ, Doyle J, Waters E. "Cochrane Update. 'Scoping the scope' of a cochrane review". Journal of Public Health.
2011;33 (1):147-50.

6. Petticrew M, Roberts H. Systematic reviews in the social sciences. Wiley Blackwell. 2006.

7. Bilotta GS, Milner AM, Boyd I. On the use of systematic reviews to inform environmental policies. Environmental Science \& Policy. 2014;42:67-77.

8. Liang TW, Feliciano DV, Koniaris LG. A surgery trainee's guide to writing a manuscript. Am J Surg. 2017 Sep;214(3):558-563.

9. Altinors N. The structure of a neurosurgical manuscript. Acta neurochirurgica Supplement. 2002;83:115-20.

10. Zimmers TA, Pierce RH, McKillop IH, Koniaris LG. Resolving the role of IL-6 in liver regeneration. Hepatology (Baltimore, Md). 2003 Dec;38(6):1590-1; author reply 1.

11. Kallestinova E D. How to Write Your First Research Paper. Yale J Biol Med. 2011;84(3):181-190. 